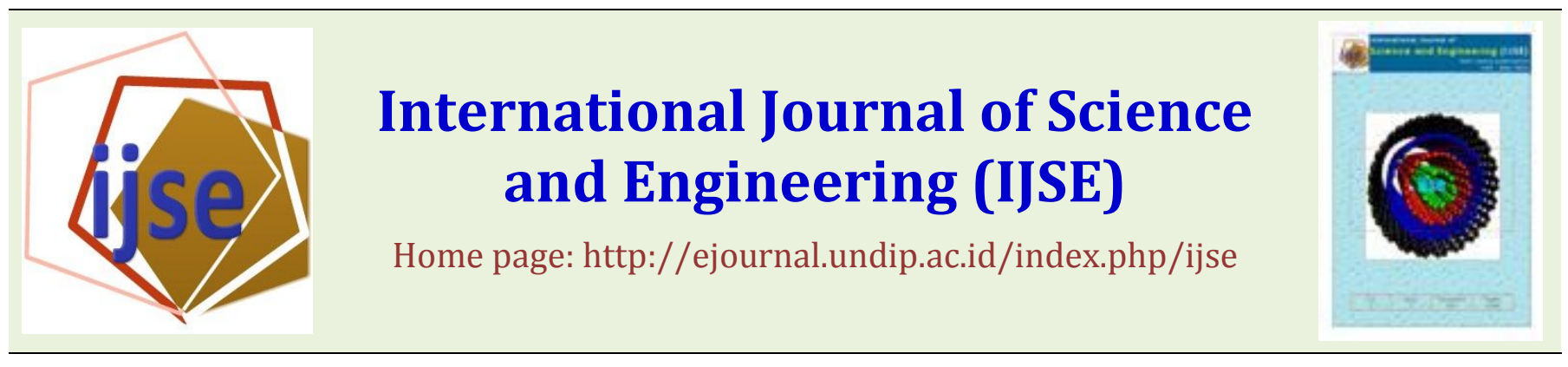

\title{
The Effects of Different Energy and Protein Ratio to Sheep's Nutrient Intake and Digestibility
}

\author{
S. Mawati $\left.{ }^{*}\right)$, Soedarsono1), Sunarso ${ }^{1)}$ and A. Purnomoadi1) \\ Email:mawati.undip@gmail.com
} 1)Faculty of Animal and Agricultural Science, Diponegoro University, Kampus drh.Soejono Koesoemowardoyo
Semarang 50275 Telp. (024)7474750 Faks. (024)7474750, Email: fp@undip.ac.id

\begin{abstract}
The objective of this research was to study the effects of different energy and protein ratio towards sheep's nutrient intake and digestibility. Twenty four male sheep's, $6-7$ months old with initial average live weight $13 \pm 1.56 \mathrm{~kg}$, coefficient variant11.78\%) were used in this research. The complete feed ration which consisted of King Grass (Pennisetum purpureum), soybean powder, rice bran, dried cassava and molasses was used in this research. Protein content on each component was 10, 12 and 14\% and total digestible nutrients (TDN) 60 and 65\%, respectively. Dry matter (DM) and organic matter (OM) intake, DM and OM digestibility were studied in this research. Analysis of variance (ANOVA) was employed to analyze the data. Test of Small Difference $(P<0.05)$ was then carried out if significant different occurred. The research results showed that Dry matter and OM ration intake showed significant different among treatments $(P<0.05)$. The highest DM intake was obtained at crude protein (CP) $14 \%$ and TDN $65 \%$ i.e. $695.54 \mathrm{~g}$ while the lowest value was CP 14\% and TDN 65\% i.e. $462.11 \mathrm{~g}$. Thus different DM and OM intake were caused by different ration ingredients composition. Dry matter and OM ration digestibility were not show different $(P>0.05)$ among crude protein and TDN treatments. Different energy and protein ration treatments caused different DM and OM intake but were not cause different in DM and OM digestibility. Based on the research results, a study on the effects of different ration's energy and protein ratio towards $N$ efficiency should be conducted in order to increase cattle productivity.
\end{abstract}

Keywords - intake; digestibility; dry matter; organic matter; energy and protein ratio

Submission: December 12, $2012 \quad$ Corrected : March 10, 2013

Accepted: March 13, 2013

Doi: http://dx.doi.org/10.12777/ijse.4.2.2013.75-78

[How to cite this article: Mawati, S., Soedarsono, S., Sunarso, S. \& Purnomoadi, A. (2013). The Effects of Different Energy and Ratio to Sheep's Nutrient Intake and Digestibility. International Journal of Science and Engineering, 4(2),76-79. Doi: http://dx.doi.org/10.12777/ijse.4.2.2013.75-78]

\section{INTRODUCTION}

Livestock situation in this present day hasn't reached its optimal development. This is reflected in the demands of accelerated development of livestock in order to fulfill fast growing needs of farm product. Therefore a comprehensive, systematic, integrated both vertically and horizontally, competitive, sustainable and decentralized strategy and policy is needed. This aims to provide adequate nutrition for people with increasing population and awareness of the importance of nutritional value, especially animal protein. Farm-based agribusiness is one of economic and social development's pillars; utilization and balance conservation of resources is the guidance of livestock development in the future.

Ministry of Agriculture has established the prospects and targets of 17 agribusiness commodities. Three of them are from livestock commodity i.e. cattle, poultry and sheep. Goat and sheep are small ruminants in Central Java with population of sheep is 2.226.709 (Animal Husbandry
Office of Central Java, 2012). Sheep is valued as a profitable livestock commodity in small farmer level due to: (1) the price is affordable by small farmers, (2) maturity is relatively fast, (3) a short reproductive cycle with two tails per birth (Iniguez et al., 1993). Those factors leads sheep as primary commodity in order to fulfill cattle meat as source of animal protein. For those reasons, an effort to increase productivity is needed to be taken through improved input especially feed (quantity and quality).

Nutrition plays an essential and special role in the systems of sheep farming for the following main reasons. First, it is the production factor that sheep farmers or keepers can act on the most easily and rapidly (amounts of feeds, composition of diets, on-feed sheep management). The management of feeding in sheep flocks depends on vegetal mass production and rangeland, pasture and crop by-product management (Fehr, 2005). 
An increased of cattle productivity will increase excreta production. Thus situation was explicitly stated by Jarvis (1999) who stated that intensified cattle production system is the primary driven factor which increases more ammonia $\left(\mathrm{NH}_{3}\right)$ enters atmosphere (approximately 50\% since 1950). Moreover, ammonia will undergo chemical change in the form of acid precipitation (due to khuluk alkali of $\mathrm{NH}_{3}$ ) and eutrophication after salt ammonium deposition $\left(\mathrm{NH}_{4}^{+}\right)$. Some efforts are needed to be taken in order to control the quality of the environment associated with the excreta. That effort is needed so it does not diminish the importance of cattle productivity improvements which aimed on improving quality of human life.

Polution control could be carried out in two ways, externally and internally. Internal handling is performed by increasing the efficiency of cattle production. This could be carried out through selecting and preparing proper feedstuffs and ration which could minimize N excreta but produces high cattle productivity. Jarvis (1999) provided an overview of the ration manipulation that allows efficient uses of $\mathrm{N}$. Thus could be obtained through provision of rations that supply protein with appropriate qualifications and amount which meets cattle needs and farm activity purpose.

Feed formulation technology which has long been known and widely used among farmers is complete feed. Complete feed is a complete balanced ration and adequate nutrition to be fed for cattle in certain physiological level as the only feeding material which could provide ability for growth, tissue conservation and also production without addition of other material except water (Hartadi et al., 2005; Sunarso et al., 2011). Complete feed ration is produced to provide a complete and practical material with adequate nutrient value to fulfill cattle needs and also to improve feeding system. In addition, complete feed will increase feeding efficiency. Complete feed uses on sheep, generally, will increase productivity resulting in more efficient uses of feed both economically and technically (Sunarso et al., 2011; Mayulu et al., 2012 Aswandi et al., 2012).

Good quality of feed is not only determined by its physical appearance (shape, particle size, color, smell and taste) and chemical (proximate analysis) but also its digestibility characteristic. The feed digestibility could be used as parameter to determine the quality (Basuki, 2000).

The feed digestibility refers to the amount that is not excreted in feses and assumed as the amount which is absorbed by animal metabolism. Feed intake amount is calculated based on the assumption of nutrient ration which is not contain in feses (Tillman et al., 1998; McDonald et al., 2002).

Feed digestibility is feed nutrient which not present in fesses. A study to determine feed digestibility could be determined by calculating the differences between nutrient intake amounts with nutrient amount present in fesses. Nutrient which not present in fesses is assumed as the digested or absorbed amount (Tillman et al., 1998). Digestibility refers to feed amount that is digested in digestive system and expressed in dry matter (Ørskov,
1992). If this value expresses in percentage it is entitled with digestibility coefficient.

The objective of this research was to study the effect of different energy and protein ratio toward sheep's nutrient intake and digestibility.

\section{MATERIAL AND METHODS}

The research was performed in Meat and Draft Laboratory Faculty of Animal and Agricultural Sciences of Diponegoro University, Semarang for five months. Twenty four male sheeps, 6 - 7 months old with initial average live weight $13 \pm 1.56 \mathrm{~kg}$, coefficient variance $11.78 \%$ were used in this research. The sheeps were lived in individual wooden stand board stable (stage enclosure) with length, width and height 150, 75 and $120 \mathrm{~cm}$, respectively. Separated feeding and drinking water were taken place on that stable. A set of maintenance equipment and metabolic stable facilities were also used such as sanitation and weight meter with capacity $300 \mathrm{~kg}(0.01 \mathrm{~kg}$ error) for cattle and $6 \mathrm{~kg}$ ( $2 \mathrm{~g}$ error) for weighing feed. The sheeps were fed twice a day at 07.00 and 16.00 WIB amounted at $4 \%$ from live weight while drinking water was given ad libitum. Remain feed was weighted before feeding application in the morning. The sheeps were weighted once a week to determine the ration needs.

The research was conducted in completely randomized design with 2 factors i.e crude protein (CP) (10, 12 and $14 \%$ ) and ration energy (60 and 65\% TDN). Each treatment was conducted in 4 replicates. The complete feed ration which consisted of King Grass (Pennisetum purpureum), soybean powder, rice bran, dried cassava (gaplek) and molasses was used in this research. Protein content on each component was 10, 12 and 14\% and TDN 60 and 65\%, respectively. Complete feed was produced from milled raw material. The end product of complete feed was in powder form not in pellet or granule. Feedstuffs material nutrient content used in this research is shown in Table 1.

Table 1. Feedstuffs Nutrient Content

\begin{tabular}{|l|c|r|r|r|r|}
\hline \multirow{2}{*}{ Feedstuffs } & \multirow{2}{*}{ Dry Matter } & \multicolumn{4}{|c|}{ Nutrient content in $100 \%$ dry matter } \\
\cline { 3 - 6 } & & $\begin{array}{c}\text { Organic } \\
\text { Matter }\end{array}$ & $\begin{array}{c}\text { Exthract } \\
\text { Ether }\end{array}$ & $\begin{array}{c}\text { Crude } \\
\text { Fiber }\end{array}$ & $\begin{array}{c}\text { Crude } \\
\text { Protein }\end{array}$ \\
\hline Rice bran & 90.08 & 92.39 & 12.77 & 15.01 & 13.05 \\
\hline Soybean powder & 89.43 & 94.16 & 18.16 & 17.28 & 42.90 \\
\hline Molasses & 63.47 & 85.38 & 0.93 & 0.08 & 3.33 \\
\hline King Grass & 89,19 & 91.16 & 1.24 & 56.76 & 3.25 \\
\hline Dried Cassava & 88,56 & 96.90 & 0.21 & 4.26 & 2.37 \\
\hline
\end{tabular}

\section{Research variable}

Feed intake. Measured feed intake was dry matter (DM) and organic matter $(\mathrm{OM})$ intake. Dry matter intake was calculated by deducting fed with remain amount and then multiply with the DM amount. Organic matter intake was calculated by multiplying the DM intake with OM amount. Feed digestibility. Feed digestibility consisted of DM and OM digestibility. Dry matter and OM were calculated by deducting DM and OM present in fesses with DM and OM intake amount.

Feed conversion and efficiency. Feed conversion was calculated by dividing dry matter intake with average of 
daily gain amount. Feed efficiency was calculated by dividing average of daily gain with dry matter intake.

\section{Data analysis}

Analysis of variance was employed to analyze the data. Test of Small Difference $(\mathrm{P}<0.05)$ was then carried out if significant different occurred. Data was processed using Statistical Analysis System (SAS).

\section{III.RESULT AND DISCUSSION}

Dry matter intake towards different energy and protein ratio in ration is shown in Table 2.

Table 2. Dry matter intake towards different energy and protein ratio on ration

\begin{tabular}{|c|c|c|c|}
\hline $\begin{array}{l}\mathrm{TDN}(\%) \\
\mathrm{CP}(\%)\end{array}$ & 60 & 65 & Means \\
\hline 10 & $548.59^{\mathrm{bc}}$ & $539.19^{\mathrm{bc}}$ & 543.89 \\
\hline 12 & $595.83^{\mathrm{ab}}$ & $555.89^{\mathrm{bc}}$ & 575.86 \\
\hline 14 & $695.54^{\mathrm{a}}$ & $462.11^{\mathrm{c}}$ & 578.82 \\
\hline Means & $613.32^{x}$ & $519.07^{y}$ & \\
\hline
\end{tabular}

Dry matter intake in energy ratio with 65\% TDN was lower than $60 \%$ TDN $\quad(p<0.05)$. That result showed that higher TDN content decreased intake amount because the sheep will stop consuming when the energy has been fulfilled. Different DM intake ration occurred because of different ration ingredients. Reksohadiprodjo et al. (1998) stated that carbohydrate type (structural and nonstructural) and degradation rate (fast or slow) have significant effect on the feed intake. High amount of Neutral Detergent Fiber (NDF) is an inhibitor for livestock's nutrient intake and uptake (Jung and Allen, 1995).

Organic matter ration intake treatment showed significant different among treatments $(\mathrm{P}<0.05)$. Different $\mathrm{N}$-energy ratio in each ration influenced the $\mathrm{OM}$ intake. The highest OM intake was obtained at CP 14\% and TDN $60 \%$ i.e. $607.17 \mathrm{~g}$ while the lowest value was CP $14 \%$ and TDN $65 \%$ i.e. 401.73 g. The different OM intake was influenced by DM intake due to different ration ingredients. DM ration has important role because the highest content in DM is OM (Tillman et al., 1998). Different CP and TDN content in ration will have different effect on OM intake (Table 3.). Thus result agreed with Oldham and Smith (1982) who stated that protein level in ration influences feed intake. Different $O M$ intake is particularly caused by different ration ingredients composition which creates on different carbohydrate type and degradation level. Ration with low NDF also influenced increased OM intake. Thus agrees with NRC (1988) who stated that high level of NDF has negative effect on feed intake.

The higher of feed digestibility amount will potentially increase absorbed nutrient content (Crowder and Chheda, 1982). In this research, factor that presumably affects good feed digestibility is high content of BETN in $\mathrm{T}_{5}$ i.e. 54.08. Anggorodi (1979) stated that BETN is easier to be digested than crude fiber in most of feed nutrient. BETN performs as energy source for rumen microbe to grow well so that the population will increase and then improve feed digestibility. Increases time period of feed holds in rumen have advantage for rumen microbe to improve their propagation which will increase fibrous degradation capability (Christiyanto et al., 2006).

Table 3. Organic Matter Ration Intake With Different Energy and Protein Ratio

\begin{tabular}{|c|c|c|c|}
\hline CP & 60 & 65 & Means \\
\hline & \multicolumn{3}{|c|}{-10-1 } \\
\hline 10 & $478.38^{\mathrm{bc}}$ & $485.88^{\mathrm{bc}}$ & 482.13 \\
\hline 12 & $518.79^{\mathrm{ab}}$ & $555.89^{\mathrm{bc}}$ & 537.34 \\
\hline 14 & $607.17^{\mathrm{a}}$ & $401.73^{\mathrm{c}}$ & 504.45 \\
\hline Means & $534.78^{\mathrm{a}}$ & $481.17^{\mathrm{b}}$ & \\
\hline
\end{tabular}

Dry matter ration digestibility treatment showed different among treatments $(\mathrm{P}<0.05)$. The highest value i.e. $67.29 \%$ which obtained by $\mathrm{T}_{5}$ treatment (CP $14 \%$ and TDN $60 \%$ ) while the lowest one i.e. $54.24 \%$ which obtained by $\mathrm{T}_{6}$ treatment (CP 14\% and TDN 65\%). Increased DM intake also caused increased nutrient and BETN intake (Table 4.).

Table 4. Dry Matter Digestibility With Different Energy and Protein Ratio

\begin{tabular}{|c|c|c|c|}
\hline CP & 60 & 65 & Means \\
\hline & \multicolumn{3}{|c|}{ 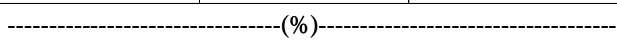 } \\
\hline 10 & $62.41^{\mathrm{ab}}$ & $64.58^{\mathrm{a}}$ & 63.24 \\
\hline 12 & $63.61^{\mathrm{a}}$ & $60.26^{\mathrm{ab}}$ & 61.94 \\
\hline 14 & $67.29^{\mathrm{a}}$ & $54.24^{\mathrm{b}}$ & 60.77 \\
\hline Means & 64.41 & 59.55 & \\
\hline
\end{tabular}

ab Different superscript in the same column and or row are significantly different at $\mathrm{P}<0.05$

BETN content in $\mathrm{T}_{5}$ considerably high i.e. 54.08 which caused feed could be digested well. It was assumed that BETN roles as the energy resource for rumen microbe so that they can grow well and increase population which lead to improved feed digestibility. BETN has better digestibility than rough fiber (Anggorodi, 1995). Produced DM digestibility value is enough to fulfill needs because ruminant only needs $50-55 \%$ dry matter digestibility (Djajanegara, 1983).

The effect of the dietary energy level on meat quality is not clear, as it is difficult to separate the level of fatness, type of diet, age or growth rate imposed. High energy diets produce more tender meat with less problematic $\mathrm{pH}$ than low energy diets due to the higher intramuscular fat content. On the other hand, food intake reduction causes increased amount and efficiency of lean production and decreased fat deposition. The raw material of the ration can affect the product quality obtained with respect to its chemical composition and energy density, digestibility, quality of taste and presence of specific substances with very specific actions. In general, the raw material as such has not been proved to be an important factor in the meat 
quality of ruminants, except with respect to the odour and flavour. It is possible that sheep meat flavour and odour is exacerbated by pasture feeding and also with age, especially from 12 months of age onwards (Zervas and Tsiplakou, 2011).

Organic matter ration digestibility showed different result among treatments $(\mathrm{P}<0.05)$. The highest value was obtained by CP $14 \%$ and TDN $60 \%$ i.e. $69,16 \%$ while the lowest one was obtained at CP $14 \%$ and TDN $65 \%$ i.e. $57.16 \%$ (Table 5).

Table 5. Organic Matter Ration Digestibility With Different Energy and Protein Ratio

\begin{tabular}{|c|c|c|c|}
\hline $\mathrm{CP} \quad \mathrm{TDN}$ & 60 & 65 & Means \\
\hline & ---------------' & (\%) & -------- \\
\hline 10 & $64,93^{\mathrm{ab}}$ & $67,87^{\mathrm{a}}$ & 66,14 \\
\hline 12 & $65,58^{\mathrm{a}}$ & $62,97^{\mathrm{ab}}$ & 63,56 \\
\hline 14 & $69,16^{\mathrm{a}}$ & $57,16^{\mathrm{b}}$ & 63,16 \\
\hline Means & 66,03 & 62,54 & \\
\hline
\end{tabular}

ab Different superscript in the same column and or row are significantly different at $\mathrm{P}<0.05$

The easier of feed digestibility will improve the capability of BO intake (Ranjhan, 1980). Feed that is easily digested will cause least amount of material that is not digested and which remains in rumen. Organic matter digestibility was in line with DM digestibility which represented that increased DM digestibility will result increased OM digestibility, vice versa due to organic matter is fraction of dry matter (Tillman et al., 1998; Orskov and Ryle, 1990).

\section{IV.CONCLUSION AND SUGGESTION}

Different energy and protein ratio on treatment caused different dry and organic matter intake and digestibility. Based on the research results, a study on the effects of different ration's energy and protein ratio towards $\mathrm{N}$ efficiency should be conducted in order to increase sheep productivity.

\section{ACKNOWLEDGEMENT}

Researcher would like to thank you to all management and staff of Meat and Draft Laboratory, Faculty of Animal and Agricultural Sciences, Diponegoro University.

\section{REFERENCES}

[1]. Animal Husbandry Office of Central Java. 2012. Livestock Statistic Data in 2011. Department of Livestock of Central Java Province. Semarang

[2]. Anggorodi, R. 1995. The Principal of Feed Animal Science. PT. Gramedia, Jakarta.

[3]. Aswandi, A., C.I. Sutrisno, M. Arifin and J. Achmadi. 2012. Effect of complete feed starch banana pea stone on the beans goats system in vivo against carcass weight and carcas part. International Journal of Science and engineering, 3(1): 26-31.
[4]. Basuki, P. 2000. A study on growth performance in fattening cattle using three levels of protein and energy feeding. Bulletin of Animal Husbandry. Supplementary edition, December 2000. pp. 193 - 203.

[5]. Christiyanto, M., M. Soejono, R. Utomo, H. Hartadi and B. P. Widyobroto. Degradation of dry matter, organic matter and crude protein ration on different PDI values in dairy cattles with feed grass basal king. Bulletin of Animal Husbandry Vol 30 (4). November 2006.

[6]. Crowder, L.V. and H. R. Chheda. 1982. Tropical Grassland Husbandry. First Published. United State of America by Longman Inc. New York.

[7]. Djajanegara, A. 1983. ed. A. T. Karoceri. LIPI, Bogor. Re-Evaluation on Rice Straw Suplement. Seminar Proceeding on the Use of Food and Agricultural Waste for Livestock Feed, ed. A. T. Karoceri. LIPI, Bogor.

[8]. Ferhr, M. P., 2005. Recent development in goat and application. Small Ruminant Research 60: 25 - 43.

[9]. Hungate, R. E. 1966. The Rumen and its Microbes. Academic Press. New York and London.

[10]. Hartadi, H., S. Reksohadiprodjo and A. D. Tillman. 1997. Table: Feed Composition for Indonesia. Ed. IV, Gadjah Mada University Press. Yogyakarta.

[11]. Iniguez, L. W.A. Pattie and B Gunawan. 1993. Aspects of Sheep Breeding for Humid Tropical Environment in Indonesia. In: Wodzcka-Tomaszewska, M., I.M. Mastika, A.Djayanegara, S. Gardiner, T.R. Wiradarya (ed) . Sheep and Goat Production in Indonesia. Sebelas Maret University Press. Srakarta. pp. 89 - 154.

[12]. Jarvis. S. C., 1999. N Potential Contamination and Flows into the Atmosphere from hearded meadow. Ed. A. P. Dewi et al. (Translated by IKIP Semarang).

[13]. Jung, H. G. and M. S. Allen. 1995. Characteristics of plant cell walls affecting intake and digestibility of forages by ruminants. J. Anim Sci. 73:2774-2790.

[14]. Mayulu, H., S. Sunarso, C.I. Sutrisno dan S. Sumarsono. 2012. The effect of amofer palm oil waste-based complete feed to blood profiles and liver function on local sheep. International Journal of Science and Enginering, 3 (1): 13-16.

[15]. McDonald, D. R., R. A. Edwards and J. F. P Greenhalgh. 2002. Animal Nutrition. $\quad 4^{\text {th }}$ Ed. LongmaNRC. 1988. Nutrient Requirements of Dairy Cattle. Sixth revised ed. National Academic Science. Washington

[16]. Oldham, J. D. and T. Smith. 1982. Protein energy interrelationship for growing and for lactation cattle. In : E.L. Miller, I. H. Piuke and A J. H. Van es (eds). Protein Contribution of Feedstuff for Ruminant. Applicaton to Feed Formulation. Butterworth Sci. London. pp. 103130.

[17]. Reksohadiprodjo, S., B.P. Widyobroto, M. Soejono, and H. Hartadi. 1998. Dairy Cattle Ration Management as a Contribution for Environmental Prevention. Faculty of Animal Husbandry Gadjah Mada University, Yogyakarta (unpublished).

[18]. Seo, J. K., J. Yang, H. J.Kim, S. D. Upadhaya, W. M. Cho and J. K. Ha. 2010. Effects of synchronization of carbohydrate and protein supply on ruminal fermentation, nitrogen metabolism an microbial protein synthesis in holstein steers. Asian -Aust. J. Anim. Sci. 23 (11) : 1455-1461.

[19]. Sunarso, L. K. Nuswantara, A. Setiadi and Budiyono. 2011. The performance of beef cattle fed by complete feed. International Journal of Engineering \& Technology IJET-IJENS 11 (01): 260-263.

[20]. Sunarso, S. 2012. The effect of King Grass silage on the nitrogen balance and hematological profile of Ettawa Grade male goat. International Journal of Science and engineering, 3 (1): 13-16.

[21]. Tillman, A.D., H. Hartadi, S. Reksohadiprodjo, S. Lebdosoekojo and S. Prawirokusumo. 1998. The Principal of Feed Animal Science. Gadjah Mada University Press. Yogyakarta.

[22]. Van Soest, P. J. 1994. Nutritional Ecology of The Ruminant. $2^{\text {nd }}$ Edition. Comstock Publishing Associates a Diision of Cornell University Press. Ithaca and London.

[23]. Zervas, G and E. Tsiplakou. 2011. The effect of feeding systems on the characteristics of products from small ruminants. Small Ruminant Research 101: 140 - 149. 